the sandwich-course method should be applied to commerce and management studies, and would like to see more pioneering experiments in a variety of fields made to guide development in years to come.

On April 29 the Minister of Education and the President of the Federation of British Industries launched a new effort to win greater financial support from local authoritios for students taking advanced sandwich courses, of which there are some 200 , with between 5,000 and 6,000 students. The target is 15,000-20,000 students, or as Mr. Geoffrey Lloyd said at a Press conference, half the technologists needed for British industry.
The Federation is recommending its member firms to pay the fees of employees who go to college and their salaries while they are there, and the Minister has issued a memorandum to local authorities, referring to firms which do not accept the Federation's advice, advising that sympathetic consideration should be given to applications for grants in such cases. It suggests that the award should cover the tuition fee in full, except where the income scale requires a parental contribution, and that earnings while the student is working should be ignored unless exceptional, as should an initial expenses allowance from the employer up to maximum of $£ 100$.

\title{
THE IMPERIAL INSTITUTE
}

$\mathrm{T}$ $\mathrm{HE}$ provisions of the Commonwealth Institute Act of March 13, 1958, were explained by the Parliamentary Secretary to the Ministry of Education, Sir Edward Boyle, in moving the second reading of the Bill in the House of Commons in February. The Trustees of the Imperial Institute receive the necessary powers to erect a new building on a new site and thus to effect the move required in consequence of the decision to expand the Imperial College of Science and Technology on the South Kensington site.

Two minor changes are proposed in the constitution of the Institute as set up by the Imperial Institute Act, 1925 : the Secretaries of State for Commonwealth Relations and the Colonies replace the Prime Minister, the Lord President of the Council and the President of the Board of Trade as trustees ; and in the appointment of the private trustees, the Minister of Education, who is responsible, is no longer required to consult the Governor of the Bank of England and the President of the Association of British Chambers of Commerce. On the change of title to the Commonwealth Institute, Sir Edward Boyle said that the change is strongly recommended by the Governors of the Institute and has been agreed in principle by all those Commonwealth Governments which have replied. The responsible Minister is empowered to dispose of or lend any object for exhibition in the Commonwealth outside the United Kingdom.

Sir Edward said that the total annual attendance in the Exhibition Galleries is now about 500,000, including, in 1957, about 1,500 parties, totalling 42,600 teachers and children. The Institute has a panel of eighty lecturers, and in 1957 about 7,000 lectures were given to audiences of about 700,000, while thirty-six conferences for sixth-form pupils, teachers and training-college students were organized in provincial centres. The Commonwealth Students'
Club, founded in 1954, has now about 300 members and forms a useful supplement to the activities of the British Council, the Colonial Office and the Commonwealth Governments in London.

The Bill was generally welcomed in the House of Commons, tribute being freely paid to the work of the Institute in spreading knowledge and understanding and promoting sound race relations, keeping before the public the great ideals which the Commonwealth represents. Nevertheless, the need for more generous financial provision was strongly urged. In reply, Sir Edward Boyle pointed out that between 1954-55 and 1957-58 the grants-in-aid increased from $£ 8,000$ to $£ 36,000$. Sir Edward did not refer to the question of the Collcutt Tower except to say that since the report on the stability of the Tower as a free-standing campanile was satisfactory, it had been decided to plan the rectangular site in South Kensington on the assumption that the Tower would be retained.

Lord Lansdowne, moving the second reading of the Bill in the House of Lords on February 27, said that for the building of the Institute $\$ 413,000 \mathrm{had}$ been subscribed from all over the Empire. For the new site of $3 \frac{1}{4}$ acres in Holland Park a capital payment of $£ 215,000$ had been made and there would be an annual rent of $£ 10$. The proposed building would have $125,000 \mathrm{sq}$. ft. of floor space. The present annual expenditure of the Institute is about $£ 94,000$, to which Commonwealth Governments contribute $£ 12,000$, the Exchequer $£ 40,000$ and the endowment fund $£ 5,000$. For the cost of the new building, $£ 725,000$ was proposed. In replying on the debate, he associated himalf with what had been said by Lords Ogmore, Dundee and Tweedsmuir as to the importance of public understanding of the Commonwealth in Great Britain and the need for adequate and effective publicity.

\section{BACTERIAL PROTOPLASTS}

$\mathrm{T}$ REATMENT of Bacillus megaterium in certain media with lysozyme converts the rod-shaped cells into spherical units which are very sensitive to osmotic shock ${ }^{1}$. These structures have been called 'protoplasts' and it has been established that the cell wall as identified mioroscopically, chemically, immunochemically, and by its reaction with bacteriophage, is entirely removed by the action of the enzyme ${ }^{2-4}$. Similar, osmotically sensitive, spherical forms can be prepared from other Gram-positive species by various techniques ${ }^{5}$. There is accumulating evidence that the cell wall is absent from such forms, although the whole of the cytoplasm is present, bounded by an osmotic barrier ${ }^{2 a, b}$ and capable of most of the activities of the intact cell ${ }^{2} \mathrm{c}$.

It is useful to have the term 'protoplast' to describe such a structure, and the phrase 'protoplast membrane' to denote the envelope which surrounds it 